\title{
The Magnificence of the Qing - European Art on the Jesuit Mission in China
}

\author{
Friederike Biebl
}

\section{Art as a bridge towards sameness}

Cross-cultural encounters between China and the West date back to the first centuries A.D., when merchants, missionaries and travelers from numerous nations undertook the journey via the Eurasian land route known as the Silk Road. However, the most productive interaction that would profoundly and permanently affect both China and Europe was stimulated by the members of a religious order founded in 1534, namely the Society of Jesus. In the following years the highly intellectual Jesuits would slowly but steadily work their way into the vast realm of Chinese life with the help of an insistent albeit accommodative propagation introducing first and foremost Catholicism, Western sciences like mathematics, astronomy and medicine, philosophy, culture as well as the arts. This policy of accommodation was introduced by the Italian Jesuit Alessandro Valignano (15391606) - responsible father in command of the China mission - and cunningly implemented by celebrated Jesuit missionary Matteo Ricci (1552-1610). Rather little attention has been paid to the subject of the arts, regarding their development and changes throughout the time of the Jesuit China missions. Remarkably, even Jean-Baptiste Du Halde (1674-1743), French Jesuit, geologist and sinologist, who is nowadays seen as the greatest author of the age on China and composer of Description de la Chine et de la Tartarie chinoise - which 
includes detailed information on the geography, culture, history, and politics of China, Chinese Central Asia, Tibet and Korea - did only briefly mention the arts in this context (Volume III, p. 1510). Even though his work is the largest and most comprehensive work on China produced by a Jesuit, he was among the Sinologists who never visited China himself. Interestingly, well-known figures such as Rousseau, Montesquieu, Voltaire, Hume and Goldsmith relied on and referred to Du Halde as their principle source of knowledge (Mackerras, 1989). We can therefore view his work as a fundamental element of how China was represented in the West - very positive, charming and slightly propagandistic. Du Halde's four-volume opus was published in 1735, when artistic encounters between Orient and Occident were about to proliferate. Indubitably, a genuine engagement of this sort is not guaranteed when two cultures meet and counteract. Prejudice and close-mindedness are prone to deteriorate cultural collaboration. This can also be applied to the case of the Jesuits and the Chinese. The old philosophical concept of alterity (otherness) immerses itself in the debate of the transformation of the individual (the self) or a group when it encounters another culture (the other). Subsequently, in the eighteenth century, when missionary work, trade and international relations flourished, the enduring question in cultural studies persisted how the Chinese would and could shape the Jesuits and vice versa. The artistic integration of East and West is not only intriguing historically but goes beyond the mere art and entertainment value when examined from other perspectives. On that account this study will investigate the European influence on Chinese art in the time frame of the late Ming to early Qing dynasty (about 1600-1765) with particular focus on the Italian Jesuit painter Giuseppe Castiglione, who served three emperors in the capital, Beijing. Hypothetically, Du Halde could have known, certainly heard about Castiglione and his achievements as he concerned himself with China in exactly the same timeframe. Can we find hints on why the subject of the arts was neglected in most Western studies? Does the status of the arts differ in Europe from the one in China? In fact, the development process of a superb Sino-Western imperial art style unfolds the most remarkable and extraordinary period in the art history of the Oing dynasty and stands for successful artistic collaboration and reciprocal curiosity in this field as well as an intriguing facet of a much broader phenomenon.

Although readers of this paper will be continuously confronted with and reminded of the subject of alterity and with the difficulties one faces when entering unfamiliar territory, this study aims at enlightening by presenting an artistic encounter of quite a different nature by stressing the positive accomplishments, similarities and outcomes, elaborating on the relationship of the Chinese Emperor and Giuseppe Castiglione. This is a story about two cultures that influenced each other in subtle ways outstretching the apparent settings 
of religion and commerce. Both China and Europe will finally be presented as mirroring cultures, with a shared genuine and avid interest in learning about the other, respect and appreciation for each other as well as equally long histories. Conjointly, the field of artistic exchange will serve as a bridge to establish common ground and agreement between two civilizations that seem mutually distant but are quite similar after all.

\section{First steps into the unknown}

Sino-European connections have always been intricate and multifaceted. Oftentimes, European travelers, traders and missionaries were anything but unified in their ambitions and encounters were prone to competition. Likewise was the case with the Chinese as they had varying opinions on foreign relations and trade. It is essential not to prescribe a subordinate role to any of the players as each of them had different motivations. During the late Ming dynasty when Europeans began to travel by sea to explore the unknown East, the emperor - who would later take on an important role in the encounter - was a remote physical presence (Demattè and Reed, 2008). In fact, he was encapsulated in the imperial palace building in Beijing. The Yangtze River delta, known as the Jiangnan area confining cities such as Hangzhou and Nanjing, on the other hand was a more receptive reference point for travelers from afar. In 1582 Matteo Ricci was among the Jesuits who found their way into China, firstly settling in Canton and other southern provinces and later in Nanjing as well as Beijing (Demattè and Reed, 2008). Although the primary goal was to convert the Chinese people to Christianity, the group introduced themselves not as missionaries but scientists and intellectuals. Provoking successful integration and impressing the Chinese elite by their broad knowledge as well as friendly and diplomatic appearance, the Jesuits were clearly seen as invaders but evoked curiosity in the Chinese at the same time. The Chinese literati - especially intrigued by Western sciences - were attracted to the Jesuits' proficient knowledge in mathematics and astronomy. During the first inquiries ideas were successfully exchanged between the two civilizations in the areas of cosmology, cartography and geography. Additionally, the Jesuits were aided by equipment they brought from home supporting them in approaching and visualizing their aims to the Chinese. Among these were clocks, maps, prisms, books as well as art works and illustrations. From the point of their arrival onwards, the Jesuits were very well aware of the potentiality of art as a missionary tool (Dourado, 2001). Eventually, these intellectual aspirations were interrupted by the fall of the Ming dynasty and the invading Manchu in 1644. The latter north Asian network established the Qing dynasty, 
which should bring even more significance to the Sino-Western exchange but would in turn add another layer of complexity. This change certainly brought additional difficulties to the fore as the Manchu rulers - well aware of their foreign origins - had a rather complex relationship with the native Han Chinese (Demattè and Reed, 2008). However, they were not in the least aversive to foreigners like the Jesuits and must have seen their great potential. De facto, the Jesuits' situation under the Qing took on a drastic change - for the Good: Between 1644 and 1705 the cross-cultural encounter was at its peak and particularly under the Kangxi emperors the Jesuits accomplished mutually satisfactory tasks. Today, Matteo Ricci is referred to as the key figure, and the first European to be fully entangled with Chinese culture, traditions, lifestyle and society (Liu, 2008). The Chinese found themselves magnetized by the humble, most wise presence of the Jesuits and Ricci describes the other in a very favorable way. He for instance praises China's prosperity: "everything which the people need for their well-being and sustenance, whether it be for food or clothing or even delicacies and superfluities, is abundantly produced within the border of the kingdom" (Mackerras, 1989, p. 33). Moreover, Ricci was struck by the apparent love for peace and harmony of the country. "Neither the king nor his people ever think of waging a war of aggression. They are content with what they have and lack any ambition for conquest. In this respect they are much different from the people of Europe", he stated (p. 33). From these words we can conclude, that China was not only foreign and strange, but also precious and desirable for the Jesuits. At the pinnacle of the Jesuit mission in China we can therefore speak of a mutually valuable conjuncture.

At this point I would like to briefly introduce the policy of accommodation the Jesuits employed keenly and with which Ricci in particular is attributed nowadays. Most importantly, I will stress that without positive reaction and interaction of the Chinese towards this policy, the Jesuits would have most certainly not reached this much in their endeavors. Correspondingly, the Jesuits had to discard some of their evangelical zeal and self-righteousness to make cooperation with the Chinese possible and to recognize the limited power Europe had in the encounter with China. According to the Belgian Jesuit and Sinologist Nicolas Standaert the process of accommodation can be divided into four steps, namely adaptation to Chinese culture and customs, propagation and evangelization 'from the top down', indirect propagation of the faith by using European science and technology, and lastly openness and tolerance concerning Chinese values (Standaert, 2010, pp. 2-6). The Jesuits occupied themselves with learning the Chinese language and adapting to the Confucian elite of literati and officials. The reason why they addressed their teachings to the Chinese high intellectuals - especially the Emperor and his court - constituted itself in the belief that if the elite would convert to Christianity, the common people would follow 
their example. Ricci admired the Chinese society who he described as having high moral standards. Due to his traditional humanistic education and compelling personality he could easily relate to Confucian thought; he even read the Confucian classics, translated them and was a welcome guest in philosophical discussions.

It was during the reign of the Kangxi emperor when the Jesuits arrived. He was keen to learn about Western science with a deep interest in the art of clock making and the conception of time. After having introduced mainly Western science to the Chinese, the Kangxi emperor's son Yongzheng was more concerned with art and architecture and admired the work of Giuseppe Castiglione and other Jesuits artists. On the other hand, he was less tolerant of Christianity and suppressed the latter in 1726, calling it a "heterodox sect" (Demattè and Reed, 2011, p. 5). However, he permitted the Jesuits he thought of as useful to the court to remain in Beijing. All Jesuits, who entered China from this point in history onwards "were looked upon as possible servants for the emperor" (Treutlein, 1941, p. 435). It was his son, the Qianlong emperor, who would be responsible to a great extent for the fruitful artistic exchange that followed the years after. Qianlong was particularly intrigued by the arts and literature and less affected by the scientific contributions of the Jesuits. Starting with his reign (1735-1796), the Jesuits were employed as artists, musicians, artisans, architects and engineers (Demattè and Reed, 2008). We can see how the interest and the will of the emperor - and only him - influenced the action and behavior of the Jesuits. One has to always recall, that the Jesuits were guests in a foreign country and even though their missions seemed to have stimulated a lot of positive response, they had to deal with competition, disagreement and most of all the adaptation to a life, completely alien to them. With that in mind, the extraordinary achievements on both the Chinese and the European side gain even more significance. The first phase of ChineseEuropean collaboration in art resulted from the introduction of oil paintings and copper engravings into China by the missionaries. At this primary encounter, stimulated by Matteo Ricci, interest was fostered yet, new styles or schools were not found (Kobayashi, 2006). Moreover, the propagation of Catholicism with the help of Western images did not happen as smoothly as wished for. Problems occurred, due to "the impossibility of directly using European conventions to aid Chinese audiences in the understanding of Christian images." Giuseppe Castiglione was sent to China not simply to create and introduce European painting but also to "translate his artistic knowledge into a visual form" (Mungello, 2008, p. 46). The change from Ming to Qing and the arrival and persistence of Giuseppe Castiglione contributed to an abundant artistic exchange and the development of a new style of art. 


\section{Giuseppe Castiglione - an Italian Jesuit on a two-fold endeavour}

Born in Milan in 1688, Giuseppe Castiglione came to Beijing in 1715 and was bound to stay for astounding fifty-one years until his death in 1766 at the age of seventy-eight. Throughout his time in China, he served the Kangxi (1662-1722), the Yongzheng (1723-35) and the Qianlong emperor (1736-95) (Mungello, 2009, p. 67). Relatively unknown in Europe, Castiglione is an established figure in China, known under the name Lang Shining (郎 世寧 / 郎世宁)and his life remains a remarkable stepping-stone for Chinese artists, art academies and museums. One can go so far in saying that he was one of the greatest court painters in the Qing dynasty and was loved by the emperor as well as the people. Like every Jesuit, Castiglione had to learn the Chinese language and adapt to the foreign customs of his host country. Having been a skilled oil-painter of the baroque tradition, Castiglione had to change his style of painting to suit the taste of the emperor (Boda, 1988, p. 44). Besides, he had the obvious obligation to convert the Chinese to Christianity and with this double assignment and complete devotion in mind, one can only imagine life at the court for him. Castiglione painted for seven years for the Kangxi emperor and established a mutual respect between them, resulting in the emperor appointing ten students to the Italian Jesuit. He taught them western techniques of oil painting, which illustrated vast differences concerning the realism and vivid colors of Europe and the seemingly flat, black and white silk paintings and engravings of the Chinese.

The Kangxi Emperor not only admired Western science, he also took an interest in the scientific mechanisms of Western perspective drawings. He was intrigued by the realistic atmosphere European paintings provided due to the use of perspective. When the emperor died in 1722 and his fourth son Yongzheng ascended the throne, Castiglione traveled to the Shuangsui valley to see the rare lotus flowers and consequently started to paint floral motives (Boda, 1988, p. 44). These paintings are characteristic for their bright colors and vitality as well as their painstakingly elegant brushwork painted with ink on silk. At this early point in his career we can already note a seemingly ease and comfort in terms of intermingling two completely different art styles. Castiglione did not strictly follow the conventions of European oil painting neither did he use a purely Chinese style. In this period he also edited the first Chinese language book on mechanics of perspective, entitled Shixue (Visual Learning) (Kobayashi, 1999, p. 262). The book was published in

collaboration with the Chinese painter, mathematician and government official Nian Xiyao, who explains the significance in the preface of Shixue: "China has cultivated a 
great tradition of depicting nature in landscape paintings but neglected the accurate representation of projection and the measurement of buildings and implements. If one desires to depict these objects correctly [in a composition], one must use the Western technique" (Kobayashi, 1999, p. 268). Here we find an explicit proof, that the Chinese were open to new techniques and welcomed the dazzling array of new creativity flowing eastwards initiated by the Jesuits. Ultimately, the stylistic foundation of Chinese painting should be rendered identic, whereas the production of realism and the detailed accuracy within the depicted space was of enormous interest.

As a matter of fact, from his seventh year on at the court, Castiglione developed a unique style, fusing the techniques of Western oil and Chinese ink. Together with other artists he worked at the imperial summer palace outside of Beijing (Boda, 1988). His status at the academy rose incessantly, and shortly after he started to paint portraits for the soon to become Qianlong emperor under who's reign Castiglione's work would flourish and bloom to the fullest. With the inauguration of Qianlong's reign in 1736, the first Imperial Painting academy was established (Kobayashi, 1999, p. 268). Around the same time, Castiglione was entitled 'official portrait painter' by the Oianlong emperor. Although he was mostly concerned and instructed to paint courtly motives, he started to occupy himself with a great variety of subjects including, birds, flowers, landscapes, hunts, architecture and portraits, according to the endeavors of the emperor, which were not always solely domestic. In 1747 construction for the Great Fountain rendered in European style architecture began and in 1751 Castiglione was commissioned to provide designs for the interior decoration (Boda, 1988, p. 44).

Court records and memorandums suggest however, that Qianlong exercised constant control of the work of his artists. This especially concerned figure paintings and imperial portraits. To achieve the best result, Castiglione worked together with Chinese artists producing art works that not only technically but also literally mixed styles. While he was skilled in painting detailed faces as well as animals, the Chinese artists would paint the landscape, background, clothing and accessories. The naturalism of the human bodies and the use of light and shadows depicted the scene, as one would view it in real life. This kind of realism was not at all stressed in Chinese traditional painting and was consequently much enjoyed by the Chinese (Kobayashi, 2006). Although it seems like Castiglione had the freedom to work creatively and independently, "a kind of tacitly understood quid pro quo arrangement existed between the Jesuit Order and the emperor, meaning that "the fathers [...] were virtual servants who did the emperor's bidding and that alone" (Treutlein, 1941, p. 436). 


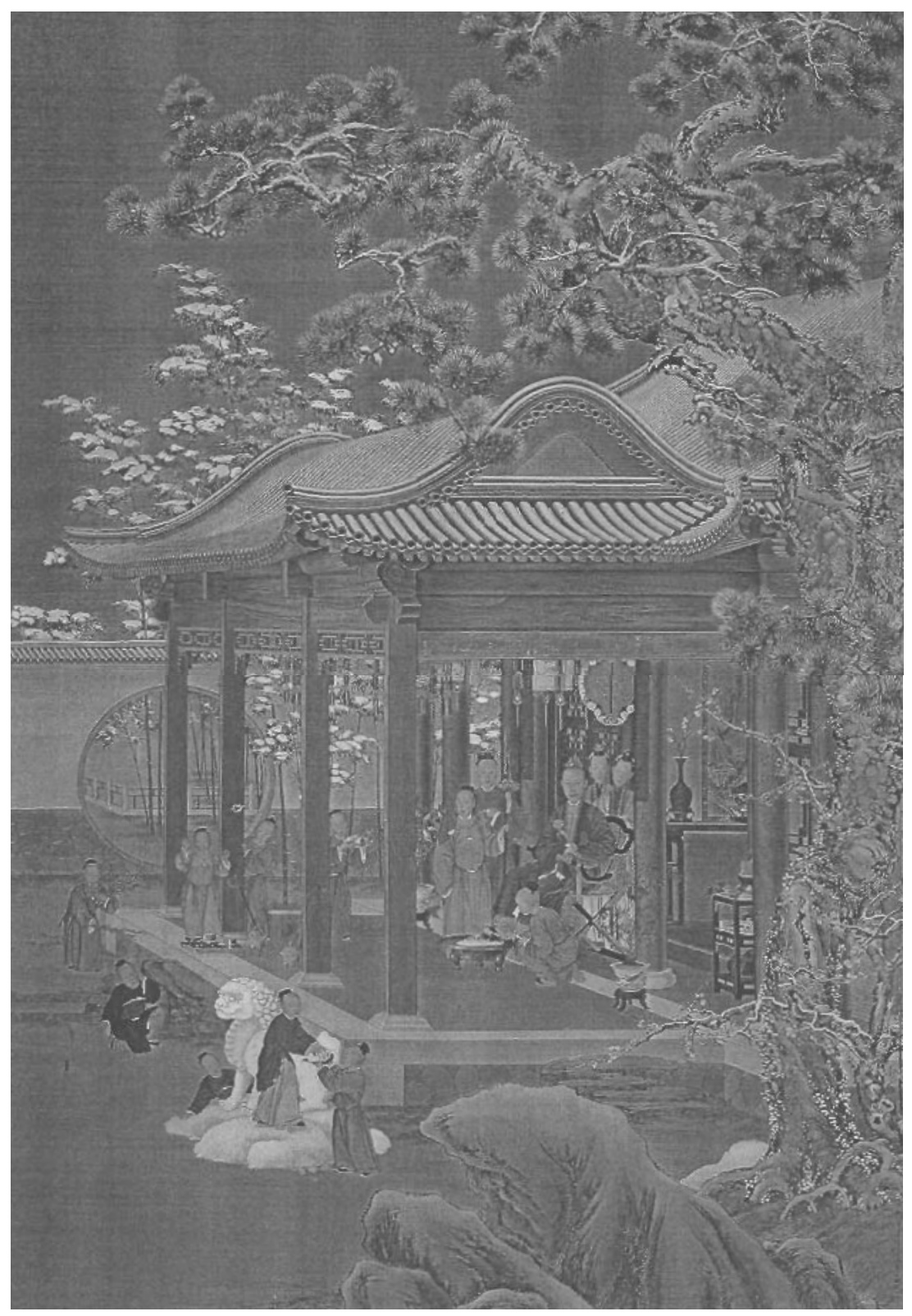

Fig. 1: The Emperor's Birthday from 1746 by Giuseppe Castiglione, Italian Ink and color on silk, Height: $305 \mathrm{~cm}$, Width: $206 \mathrm{~cm}$, The Palace Museum Beijing 
Under Qianlong, Castiglione was eventually ranked third-class official and was awarded vice president of one of the Six Boards - the highest award a Jesuit ever attained (Boda, 1988, p. 46). Well-trained in drawing and painting, Castiglione was the only painter able to practice oil painting techniques when he arrived in Beijing. As mentioned before, oil painting was not the only concept brought to China, but also Western perspective was introduced. At the court, one referred to it as art works in the xianfa style, meaning line method' and explaining the phenomenon of Western linear perspective and vanishing point projection commonly used in European paintings and drawings. Xianfa was especially applicable to architecture and landscape paintings and could be brilliantly combined with gongbi, the traditional way of Chinese realistic representation as well as jiehua, an accurately executed insertion of brush, ink and pigments (p. 49). Xianfa was ultimately used for all kinds of subjects and the emperor adored its true-to-life effect in space and distance (see Fig. 1). In the aforementioned illustration the viewer is exposed to the Western technique of chiaroscuro (Italian for dark-light) introduced by the Jesuits, which stands for stark contrasts between light and shadow, achieving a three-dimensional volume, which boldly affects the whole composition. Castiglione was the artist to promote chiaroscuro as well as western arrangement of motives and was praised as a master of "naturalistic draftsmanship and large-scale compositions" (Hearn, 2003). Through the work of Castiglione, Xianfa turned out to be a prominent art style closely related to the Imperial Academy and although the Italian painter taught it to various Chinese artists, they needed his assistance until the end. As Boda notes, "only a small proportion of the academy mastered it and were specifically appointed to paint in this style" (Boda, 1988, p. 49). Yet, some Chinese artists such as Jiao Pingzhen (1680-1720) and Leng Mei (1662-1722) successfully applied the Western perspective to their works. 


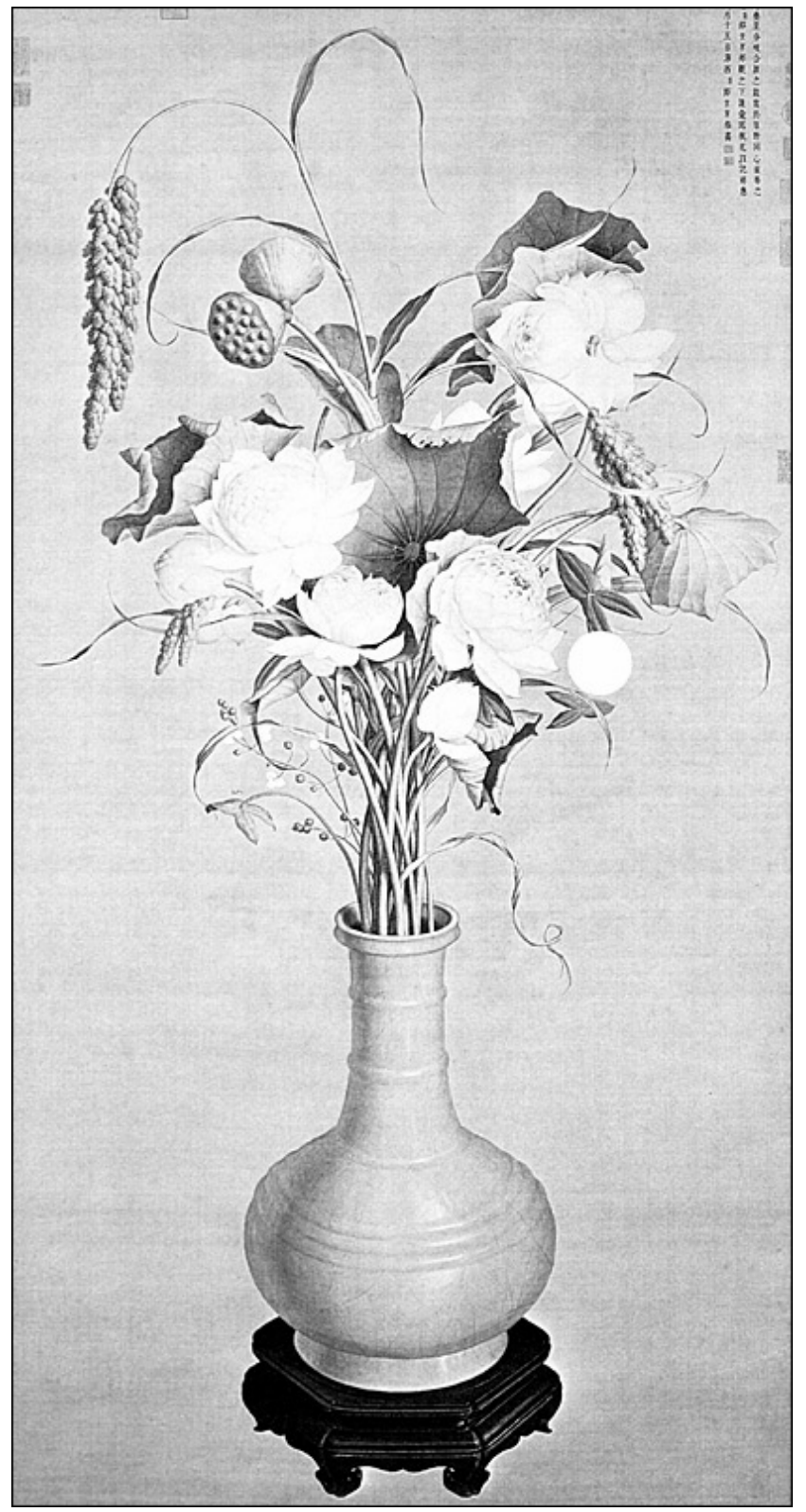

Fig. 2: Assembled Auspicious Objects, by Giuseppe Castiglione, Italian painting on silk, Height: $173 \mathrm{~cm}$, Width: $86 \mathrm{~cm}$, The National Palace Museum, Taipei. 
In the following I will briefly introduce a few works done by Castiglione at the court emphasizing the various features which contributed to a new art style that deserves admiration. Assembled Auspicious Objects (Fig. 2) was painted in the Yongzheng period and clearly employs the chiaroscuro technique explained above. The painting is rendered three-dimensional therefore dwells on the typically European artists' concern of depicting plasticity in space on a flat surface. Overall, the painting is harmonious and the contrasts are not too strong. Besides, Castiglione successfully employed Chinese media with a line and color technique reminding of the gongbi style. The Jesuit artist was particularly gifted in portrait painting and finalized portraits of Oianlong when he was quite young until he was forty-five years old. This series of portraits not only show the distinct features of the emperor growing older but also exhibit the artistic development of Castiglione (Boda, 1988, p. 51). Figure 3, the Portrait of the Emperor Qianlong in Ceremonial Dress, demonstrates the extremely defined and exclusive method of Castiglione. Not only did he achieve great realism, he connected "strong and weak frontal lighting, subtle shadowing and the use of pink and white to give the face a certain effeminacy" (Boda, 1988, p. 51). Likewise, the pupils seem gloomy and a distinctive highlight accompanies the nose. In this painting, Qianlong is presented as being intelligent, gentle and wise, which is emphasized by the calm sitting posture, the resting position of the hands and not least his blissful, gazing facial expression. All these features seemingly accentuate his brilliance, good will, and sublime authority. We can see, that although Castiglione's style greatly differed from his Chinese contemporaries, it was highly appreciated the court. Unfortunately as a result of aging, poor preservation, war and fire, only few of his works are still accessible and survived at the Qing court (Boda, 1988, p. 46). During the eighteenth century, Castiglione helped realizing various architectural projects although he was never particularly trained as an architect. The most challenging and known task was the design and construction of the European Palaces at Yuanming Yuan (Boda, 1988, p. 51). The latter was designed in Italian Baroque style and decorated after concepts of the Qianlong reign. 


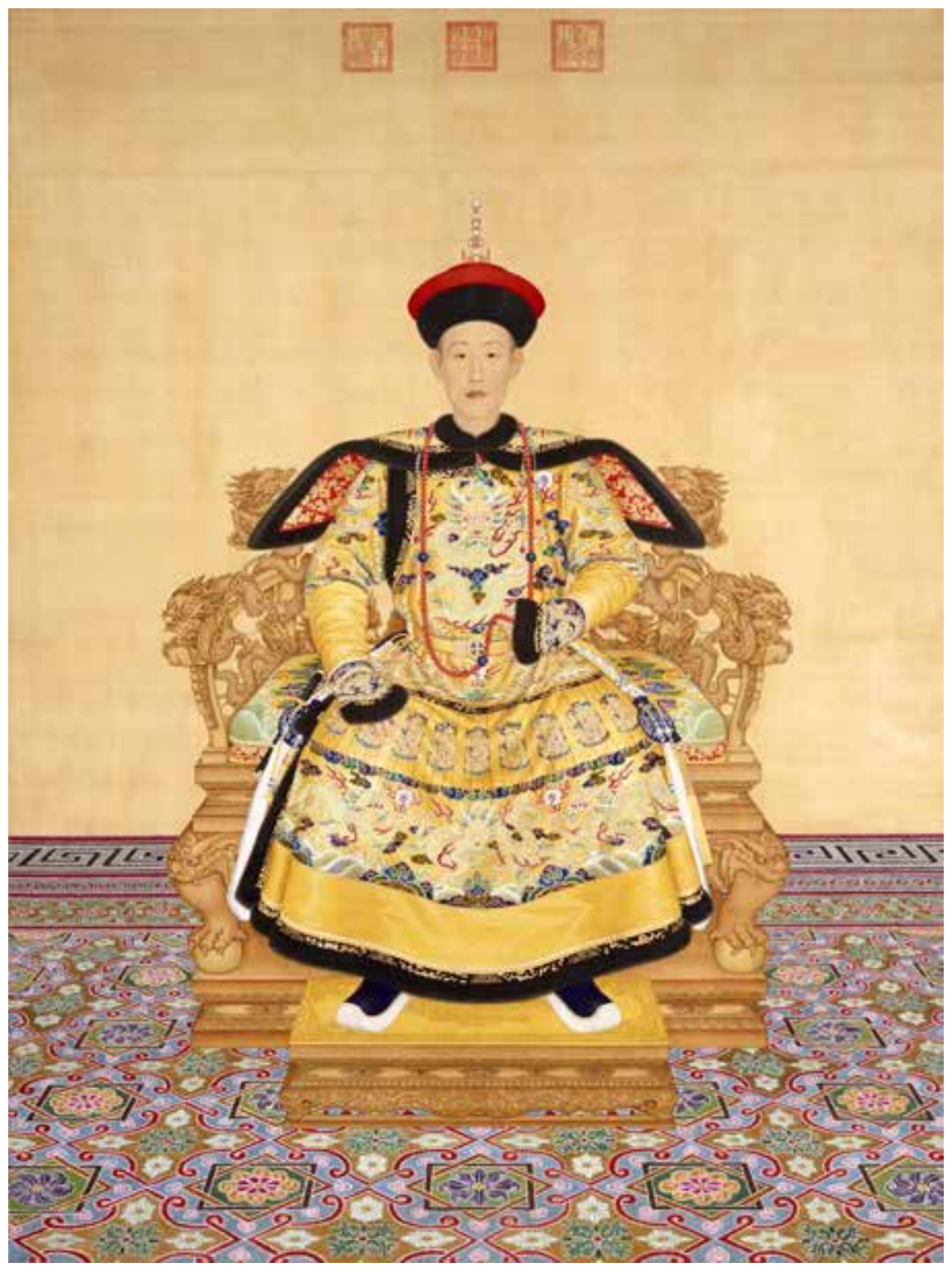

Fig. 3: Portrait of the Emperor Qianlong in Ceremonial Dress by Giuseppe Castiglione, Italian ink and color on silk, Height: 242,2cm, Width: $179 \mathrm{~cm}$, The Palace Museum, Beijing. 
Given these facts, Giuseppe Castiglione was an essential advocate of the xianfa style, originator of a new Sino-Western art style, architect as well as talented craftsman. His career displays a half-century of creativity and artistic skill, which ingeniously blended Chinese and Western techniques and should in no way be underestimated (Boda, 1988, p. 51). It is essential to note, that Castiglione's achievements "arose from his knowledge of his imperial patron's taste, and the cultural and political context in which the paintings had to function" (Musillo, 2008, p. 48). Assessing Castiglione's work in China is a two-fold endeavor. Therefore, his painting expertise as well as his behavior as a courtier has to be taken into account. The Memoria (memoir) of Castiglione, written by an anonymous author after his death gives important insights into life at the court for the Jesuit brother and professional painter. In the very beginning of the Memoria, the author glorifies Castiglione as a devout Jesuit and just as much an excellent painter:

"Among those who passed away with great mourning [...] one should mention the well-known Brother Castiglione. He was greatly endowed with all those qualities that our Society appreciates in a brother coadjutor... [...] The present Emperor [...] had so high an opinion of his piety that he believed that a similar man could not be found all over the world. One can imagine the Emperor's word: 'Are there in Europe such excellent artists as you are?' Castiglione would have replied: 'There are many indeed.' And the Emperor pressing him back: 'And would I find one as virtuous as you are?"'

(Musillo, 2008, p. 49).

From these passages, the reader is compelled to view Castiglione's case as a combination of moral virtue and artistic talent. According to Musillo, the emperor did not present an obstacle as a non-Christian as often assumed. In reality, he appreciated Castiglione's art in the same way as his persona and evidently recognized his qualities to the court. Although Castiglione was undoubtedly a servant at the Imperial Court, he managed to not only fulfill the wishes of the emperor but was able to commit to the Jesuit value of humbleness and frugalness regardless of his fame at that point in time. It follows another paragraph of the Memoria describing Castiglione's work under Qianlong:

"[...] Since he was a child, he was an admirer of Castiglione and developed a great love and filial affection for him. As soon as he became the Emperor, he could not stand the fact that the worthy old man did not have any honors, so he decreed that he would enter the Order of Mandarins. [...] A lot of people started to congratulate 
him openly on what they thought was a settled fact, but the virtuous old man abhorred these kinds of honors, [...]. So while asking God for what he had to do to avoid those honors [...] he looked unusually sad so that his friends took it as a clear sign of his unwillingness to accept such a favor: a clear sign indeed also for the Emperor, who as he did not want to afflict the very person he wanted to gratify, recalled the decree, something which rarely happens. Castiglione's humility had prevailed." (Musillo, 2008, p. 54).

For the Jesuits humility was not only a favorable personal attribute but a vital means of serving the first vow of poverty. Living this vow was not a simple task for Castiglione. It was binding for him to accept honors and gifts from the emperor to perpetuate a professional relationship. On the other hand this kind of relationship conflicted with his Jesuit life membership. On top of that, the relationship of the emperor and the Jesuit fostered resentment and jealousy among the other artists and led to a competitive and hostile atmosphere at the court. While Castiglione is represented as the modest missionary, he also gracefully maintained the Jesuit presence in the Chinese capital. The Memoria was the first manuscript that linked "the political dimensions of his career to his painterly oeuvre" (Musillo, 2008, p. 57).

\section{A memorable artistic interchange on shared terrain}

Two-hundred-ninety-eight years ago, Giuseppe Castiglione went on a mission. He lived, served and finally found his eternal rest in a foreign country. Accompanied by ingenious fate and talent, he integrated Eastern and Western art resulting in a new school of painting for China (Dourado, 2001). Although his evangelistic mission was almost forgotten, the reader of this paper has been presented with the fruitage of the hard labor of a faithful lay brother and Imperial Qing painter. Indubitably, the remarkably respectful relationship between the Emperor and the Italian Jesuit played an essential role in the outcome of the grandeur of the Qing dynasty. Picking up the famous persona of Jean-Baptiste Du Halde one more time, one could argue that it is striking he did not even consider writing about this artistic exchange. With good judgment one could go so far in offering the following solution for that concern: "In China, as in Europe and in other cultures, the visual arts are ranked hierarchically depending upon their function, materials, themes, and most importantly the social position of those who practice them" (Ledderose, 1991, p. 221). In traditional China, the literary arts such as calligraphy took on the highest position closely followed by 
painting. Other art forms were mostly seen as crafts that required skill; under this category fell book illustrations, print making, seal carving and garden design. However, sculpture as well as the applied arts never gained renowned status nor did architecture. Unlike so in Europe: “Architecture was seen as 'the mother of the arts' and therefore occupied the most prestigious position together with sculpture, painting and finally the applied arts and decorative art" (Ledderose, 1991, p. 221). All other arts were seen as supplements that could enhance the aesthetic appeal of an architectural site. Hence, one can state, that the more influence a certain art style had in China, the less it had in Europe and vice versa. This may also explain why Europe mainly imported porcelain, lacquerware, wallpaper, and furniture from China, which occupies a rather low status in its home country, while Europeans were not interested in the literary arts most praised in China. On a broader level we can now relate this phenomenon to the literature written about this subject. I already mentioned, that while Castiglione is widely known in China, he is unfamiliar to most people in Europe. Likewise, as the decorative arts have a low status in China, chinoiserie is what Europeans consider to be 'art from China'. Admittedly, while Jesuit artists and art on the missions in general represented an evangelizing medium, it surely did not influence the outcome to the same extent as the introduction of Western science did. Moreover, Castiglione did now enjoy a long-lasting or even international fame. This paper aims at changing that. In fact, Castiglione's personal story represents the hidden treasure of a noteworthy and efficient collaboration between East and West, which is certainly inspiring and will eventually find its way to a much broader audience. Influential authors like Du Halde oftentimes stressed positive encounters and enthusiasm on equally both sides, however, "the emperor himself decided which missionary would serve him and which ones would be free to proselytize" (Treutlein, 1941, p. 436). Given this fact, one has to value the Sino-Western relations also in the light of the emperor's self-interest.

Above all, in the artistic area we have seen a positive alliance of the other and the self. The Jesuits may have gone to China to convert the Chinese and to teach Western thought; despite all, they were deeply engaged in the life and culture of the locals which lets us conclude that the similarities between the two civilizations overweight the differences. It was a process of on the one hand blending in and on the other standing out that required mutual understanding (Liu, 2008). The Jesuits as well as the Chinese succeeded in focusing on their affinities and were transformed through each other resulting in the creation of an artistic product they could be proud to share. 


\section{Bibliography}

Bailey, G.A. (2001). Art on the Jesuit Missions in Asia and Latin America. 1542-1773. Toronto: University of Toronto Press.

Boda, Y. (1988). Castiglione at the Qing Court. An Important Artistic Contribution. Orientations 19(11), 44-51.

Demattè, P. \& Reed, M. (2008). China on Paper: European and Chinese Works from the Late Sixteenth to the Early Nineteenth Century. Los Angelos: Getty Research Institute.

Dourado, E. (2001). The Golden Exile. Extracted from: http://www.mam.gov.mo/shows/ exile/english/preface_e.htm

Du Halde, J.B. (1736-1737). Description géographique, historique, chronologique, politique, et physique de l'empire de la Chine et de la Tartarie Chinoise, enrichie des cartes générales et particulieres de ces pays. (4 volumes). La Haye: Henri Scheurleer.

Hearn, M.K. (2000). The Qing Dynasty (1644-1911). The Courtiers, Officials and Professional Artists. In: Heilbrunn Timeline Time Line of Art History. New York: The Metropolitan Museum of Art. (http://www.metmuseum.org/toah/hd/qing_4/hd_qing_4.htm)

Hearn, M.K. (2005). The Grandeur of Art during the Qing. Extracted from: http://www.learn. columbia.edu/nanxuntu/html/art/

Kobayashi, H. \& O'Malley, J.W. (2006). Suzhou Prints and Western Perspective: The Painting Techniques of Jesuit Artists at the Qing Court, and Dissemination of the Contemporary Court Style of Painting to the Mid-Eighteenth-Century Chinese Society through Woodblock Prints. In J.W. O'Malley (Ed.). The Jesuits II: Cultures, Sciences, and the Arts, $1540-1773$ (pp. 262-286). Toronto: University of Toronto Press.

Ledderose, L. (1991). Chinese Influence on European Art, Sixteenth to Eighteenth Century. In T.H.C. Lee (Ed.). China and Europe, Images and Influences in the Sixteenth to the Eighteenth Century. Hong Kong: the Chinese University Press. 
Liu, Y. (2008). The Intricacies of Accommodation: The Proselytizing Strategy of Matteo Ricci. Journal of World History 19(4), 465-487.

Mungello, D. (2009). The Great Encounter of China and the West, $1500-1800$ ( $3^{\text {rd }}$ ed.). Lanham: Rowman and Littlefield.

Musillo, M. (2008). Reconciling Two Careers: the Jesuit Memoir of Giuseppe Castiglione Lay Brother and Qing Imperial Painter. Eighteenth Century Studies 42(1), 45-59.

O'Malley, J.W. (Ed.) (2006). The Jesuits II: Cultures, Sciences, and the Arts, 1540-1773. Toronto: University of Toronto Press.

Standaert, N. (2010). Mateo Ricci. Shaped by the Chinese'. Thinking Faith: The Online Journal of the British Jesuits, 21 May 2010, 1-8. Retrieved from http://www.thinkingfaith.org/ articles/2010052_1.htm.

Thompson, C. (2011). Travel Writing. London - New York: Routledge.

Treutlein, T.E. (1941). Jesuit Missions in China during the last Years of K'ang Hsi. Pacific Historical Review 10(4), 435-446. 


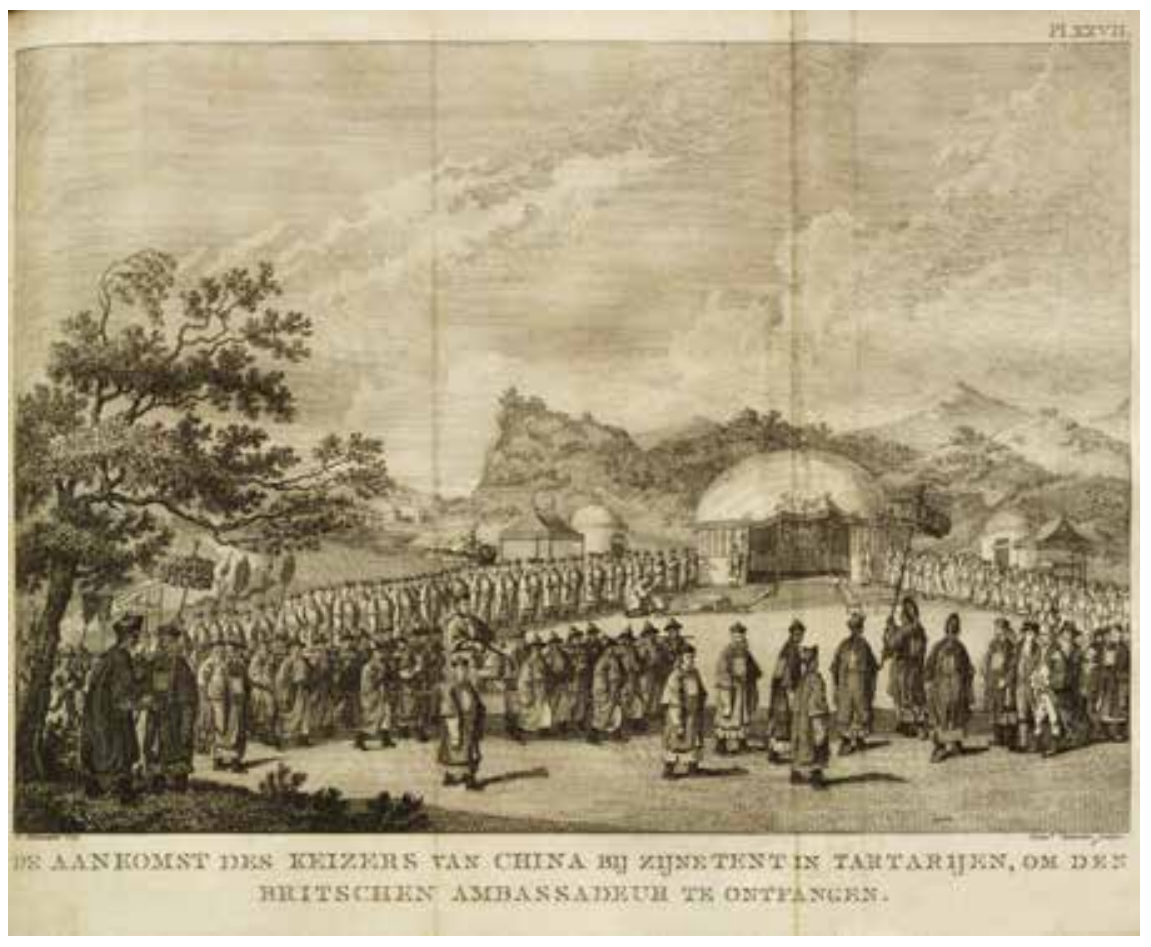

Arrival of the Chinese Emperor at his marquee in Tartary, in order to see the British Embasy.

Source: Staunton, G.L. (1798-1801). Reis van Macartneij, naar China / door George Staunton; uit het Engelsch; met plaaten en kaarten. Vol. 1-7. Te Amsterdam: bij Johannes Allart. 